\title{
MLA-Based Detection of Organic Matter with Iodized Epoxy Resin-An Alternative to Carnauba
}

\author{
Anne Rahfeld*, Jens Gutzmer \\ Helmholtz-Zentrum Dresden-Rossendorf, Helmholtz Institute Freiberg for Resource Technology, Freiberg, Germany \\ Email: *a.rahfeld@hzdr.de
}

How to cite this paper: Rahfeld, A. and Gutzmer, J. (2017) MLA-Based Detection of Organic Matter with Iodized Epoxy Resin-An Alternative to Carnauba. Journal of Minerals and Materials Characterization and Engineering, 5, 198-208.

https://doi.org/10.4236/jmmce.2017.54017

Received: March 23, 2017

Accepted: July 2, 2017

Published: July 5, 2017

Copyright (ㅇ 2017 by authors and Scientific Research Publishing Inc. This work is licensed under the Creative Commons Attribution International License (CC BY 4.0).

http://creativecommons.org/licenses/by/4.0/

\begin{abstract}
Solid organic matter is an important constituent not only in coal, but also in black shale-hosted ore deposits. The reliable recognition and quantification of organic carbon-as well as its microfabric relation to associated inorganic minerals-plays a crucial role in characterization by scanning electron microscopy-based image analysis. However, the use of conventional epoxy resin in the preparation of grain mounts does not allow for recognition of solid organic carbon compounds. In this study we illustrate that the use of iodized epoxy resin readily overcomes this bottleneck. Best results are obtained with an addition of $15 \mathrm{wt} \%$ iodoform to the epoxy resin. With process samples of black shale-hosted polymetallic Kupferschiefer-type ore as a case study, it is shown that recognition and quantification of solid organic carbon are easily achieved and that tangible parameters such as particle and grain sizes, association and liberation for ore and gangue minerals can be determined in the presence of solid organic matter. Due to the inherent uncertainty of the exact chemical composition of the kerogen contained in Kupferschiefer, it was not possible to attain exact comparability between chemical $\mathrm{C}_{\text {org }}$ assays and assays calculated from MLA data. However, the results are still found to closely agree with one another. The strength of iodized resin lies in its ability to distinguish organic matter with high hydration ratios in addition to the easy integration in sample preparation. It could therefore be an attractive supplement in the analyses of other raw materials containing complex organic-matter.
\end{abstract}

\section{Keywords}

SEM-Based Image Analysis, Epoxy Resin, Iodoform, Organic Matter, Kupferschiefer

\section{Introduction}

Understanding the nature and composition of raw materials is of utmost importance 
to optimize beneficiation processes. This requires not only chemical assays, but also quantitative mineralogical and microfabric data [1]. SEM-based image analysis (aka automated mineralogy) provides readily access to such quantitative data. Difficulties arise, however, when the studied raw materials are rich in solid organic carbon, such as coal or polymetallic base metal ores hosted by carbonaceous shales [2] [3] [4]. In this study we investigate samples of Kupferschiefertype ores from Poland and Germany. A dominant portion of the mineral resource of the Kupferschiefer is hosted by highly carbonaceous shale, the Kupferschiefer sensu strictu. This thin black shale unit is underlain by sandstone and overlain by limestone, both of which may be mineralized as well [5]. The hydrothermal sulphide assemblage of the Kupferschiefer is complex, with bornite, chalcocite, chalcopyrite, pyrite, sphalerite, and galena as major-and tennantite and cobaltite, amongst numerous others [6], as minor constituents. In the Kupferschiefer s.s. these sulphides are finely disseminated in a very fine-grained matrix comprising of sheet silicates, carbonate minerals and solid organic carbon that occurs in thin, bedding parallel streaks and lenses [5]. The Kupferschiefer contains on average $5 \mathrm{wt} \%$ total organic carbon (TOC) [7] [8]. The organic matter associated with Kupferschiefer has been described to contain a wide and versatile spectrum of organic compounds, including aliphatic compounds, aromatic compounds, acid esters, and porphyrins [8] [9] [10] [11]. Most occurs as solid kerogen type II [12], but occurrences of liquid hydrocarbons as inclusions in carbonate minerals have been described [13].

The organic matter of the Kupferschiefer s.s. may form thin films around ore and gangue mineral particles; it is also hydrophobic and interferes in the sulphide flotation processes. Furthermore, it is known to negatively affect pyrometallurgical processes [14] [15]. From the above, it is apparent that quantitative knowledge is needed concerning the abundance and distribution of the organic carbon during process mineralogical studies of the Kupferschiefer. Automated mineralogy is widely accepted as an analytical tool well-suited to quantify mineralogy and relevant microfabric parameters [2] [16] [17]. It combines highresolution backscatter electron (BSE) images with energy-dispersive X-ray (EDX) measurements to determine the chemical composition and distribution of minerals on a defined polished surface. The use of supporting data evaluation software, in this case FEI's Mineral liberation analysis suite (MLA), delivers microfabric information in terms of association, liberation, and distribution.

However, solid organic carbon residues can generally not be differentiated from the epoxy resin that is used to produce grain mounts for granular process samples. In such cases, the organic carbon remains unnoticed-resulting in erroneous results. Different approaches have been proposed to overcome this particular problem in the analysis of organic-rich materials [3] [17], but are not entirely suitable for the analysis of organic matter in Kupferschiefer-type ores. Within this study we document that the addition of iodoform to epoxy resin is an attractive and practical alternative that is well suited to recognize and quantify the abundance of organic carbon in metalliferous black shales. 


\section{Sample Preparation and Analysis}

Within the context of automated mineralogy, organic matter can be differentiated from (inorganic) minerals based on the difference in BSE grey values (contrast) or the presence of carbon by EDX. Contrast in BSE images corresponds to differences in chemical composition largely determined by the average atomic number (AAN). In cases where crushed or milled samples are studied, commonly the case in the study of processing products, the embedding media interferes in the detection of organic matter because of the low contrast between organic matter and epoxy [18]. Traditional epoxy resin has a similar composition and AAN to organic matter, meaning that it appears in a similar BSE grey level and cannot be differentiated by EDX.

Two options have been employed in the past to accomplish the distinction between solid organic matter and epoxy resin. One can either increase the AAN of the epoxy by using a halogenated epoxy and change the EDX signal or use carnauba wax, which has a lower AAN (Table 1). Halogenated epoxy can be recognized as an independent phase and included within the analysis based on its distinctive chemical composition and grey value. Its use additionally minimizes difficulties during the polishing process or the high risk to cause contamination of the BSE and EDX detectors during measurement that is associated with the use of carnauba [18] [19]. Chlorinated epoxy is commonly used in the analysis of coal [17], but has not achieved an entirely satisfactory contrast [3]. Creelman and Ward [3] recommended the addition of iodoform to increase the contrast between coal particles and the epoxy resin. EDX signals of brominated epoxy have an interference of $\mathrm{Br}$ and $\mathrm{Al}$, and are therefore not regarded as suitable [20]. Carnauba wax has been successfully used in the study of coal samples [16] [21]. In this study, both approaches were tested in an effort to reliably identify and quantify the presence and abundance of kerogen in process samples of Kupferschiefer.

Three Kupferschiefer samples, collected from the Polkowice-Sieroszowice and Rudna mine sites in Poland (P-KS-2, P-KS-3, R-KS), were investigated. These samples comprise of sulphides, carbonates, silicate minerals, and kerogen (Table 3, Figure 4). In addition, a flotation concentrate obtained from a mixture of Kupferschiefer ore lithotypes (black shale, sandstone, carbonate) was supplied by KGHM (L-KS-Con). The TOC ranges from 3.4 to $9.6 \mathrm{wt} \%$. All four samples have been milled to $<100 \mu \mathrm{m}$, the grain size used for their flotation, and were prepared

Table 1. Average atomic numbers $\left[16^{1}, 21^{2}, 22^{3}\right]$.

\begin{tabular}{ccc}
\hline & AAN \\
\hline Carnauba wax $^{1,2}$ & 5.36 \\
Kerogen type II & $5.5-5.9$ \\
Coal $^{1}$ & $6.27-7.28$ \\
Graphite $^{3}$ & 6 \\
Silicates & $>10$ \\
\hline
\end{tabular}


in grain mounts for MLA analysis. Both iodized resin and Carnauba wax were used as resin for grain mount preparation.

Iodized epoxy resin was freshly prepared following Gomez et al. [20] with 99\% pure iodoform $\left(\mathrm{CHI}_{3}\right)$ supplied by Alfa Aesar $\mathrm{GmbH} \&$ Co KG. However, a dissolution time of 30 minutes - as recommended by Gomez et al. (1984) - was found to be insufficient. Full dissolution of 10 to $15 \mathrm{wt} \%$ iodoform in $50 \mathrm{~g}$ of epoxy resin in a water bath at $50^{\circ} \mathrm{C}-70^{\circ} \mathrm{C}$ required 60 to 90 minutes under gentle stirring. The iodized epoxy was cooled to room temperature. The grain mounts were prepared of a mixture of $3 \mathrm{~g}$ milled sample material with $2 \mathrm{~g}$ iodized epoxy resin. The ratio of sample material and resin was chosen as to minimize sedimentation effects during preparation [23]. Best results were achieved with an iodized resin carrying $15 \mathrm{wt} \%$ iodoform. The amount of added iodine directly controls the increase in grey value observed in BSE. Recrystallization was observed in samples containing $20 \mathrm{wt} \%$ iodoform, whereas $10 \mathrm{wt} \%$ of iodoform was not sufficient to distinguish the organic matter and the epoxy resin in BSE images. The iodized epoxy was always freshly prepared and was, when used, never more than two weeks old. We observed no adverse effects of ageing of the iodized resin, although a change in colour from orange to dark red was observed. The latter is attributed to light-induced (UV radiation) decomposition of iodoform. Araldit 2020 was used as basis for the resin. It has optimal characteristics for the preparation of polished grain mounts. Trials with Araldit Klebstoff B1 were less satisfactory. It had a higher viscosity, which made the dissolution of iodoform more difficult and took longer to harden.

Carnauba wax was also tested in this study. In this case, one gram of a single sample was imbedded in $4 \mathrm{~g}$ wax. The sample was placed in an oven at $90^{\circ} \mathrm{C}$ for ca. 2 hours to melt the wax. Afterwards the temperature was reduced to $40^{\circ} \mathrm{C}$ to slowly harden. The wax blocks were lastly embedded in epoxy resin. Due to its softness carnauba wax requires an adaptation in the polishing process as compared to epoxy resin. However, carnauba wax was found to not yield a sufficient contrast to the organic matter of the Kupferschiefer. Immature, hydrogen-rich kerogen, found within Kupferschiefer [9], possess a lower AAN than coal and BSE grey levels between carnauba and organic matter are almost identical. No further tests were thus carried out with carnauba wax.

Polished grain mounts were carbon-coated prior to analysis to ensure a fully conductive surface. Image analysis was completed on a FEI Quanta 650 field emission SEM equipped with two Bruker Quantax X-Flash 5030 EDX detectors (Table 2). FEI's MLA suite 3.1.4 was used for data acquisition and processing.

Measurement files were processed twice, once identifying inorganic minerals as well as organic matter and a second time excluding any detected organic matter from the analysis and adding it to the background. This way, the effect and importance of detected organic matter on the acquired data set in terms of liberation and particle size estimation is illustrated without adding additional sources of error. The data is presented in mineral groups to improve the clarity of the data (Table 3 ). 
Table 2. Measurement conditions for the SEM-based image analysis.

\begin{tabular}{llll}
\hline MLA measurement settings & & & \\
\hline Accelerating voltage & $15 \mathrm{kV}$ & Brightness & 29.65 \\
Beam current & $10 \mathrm{nA}$ & Contrast & 93.92 \\
Working distance & $13 \mathrm{~mm}$ & Measurement mode & GXMAP \\
HFW & 500 & Magnification & 476 \\
& & Step size & 5 \\
\hline
\end{tabular}

Table 3. Overview of grouped minerals used in the data evaluation.

\begin{tabular}{llllll}
\hline Grouping & Included minerals & & & \\
\hline Quartz & Quartz & & & \\
Sheet silicates & White mica & Kaolinite & Fe-Mg sheet silicate & \\
Carbonates & Dolomite & Ankerite & Calcite & & \\
Ore minerals & Chalcocite & Bornite & Chalcopyrite & Covellite & Azurite \\
& Atacamite & Malachite & Tennantite & Enargite & (Ni-)Cobaltite \\
& tGalena & Anglesite & Cerussite & Sphalerite & Stromeyerite \\
Accessories & K/Na-Feldspars & Barite & Celestine & Gypsum & Pyrite \\
& Apatite & Rutile & Titanite & Zircon & Marcasite \\
Organic & Organic matter & & & & \\
\hline
\end{tabular}

\section{Results and Discussion}

The iodized epoxy resin was stable under the electron beam. No detrimental effect on the detection of any of the inorganic minerals was noticed. The differentiation between organic matter, iodized resin, and inorganic minerals was achieved easily either based on the difference in grey values or based on EDXspectra (Figure 1). Iodized epoxy resin is characterized by three major iodine peaks between 3.8 to $4.1 \mathrm{keV}$ that stand out in any spectra of the resin. Potential interference is only encountered with the Ti-Ka peak, but posed no issue for correct mineral identification in this study.

Using this approach, it was possible to quantify the organic matter content as part of the modal mineralogy (Figure 2). The detected organic matter correlates well with the TOC values obtained by chemical assay and agrees by order of magnitude (Table 4). It is, however, obvious that MLA data consistently underestimate organic carbon abundances. Unfortunately, the precise TOC content cannot be calculated from the MLA results, as it is known that the maturity of kerogen in the Kupferschiefer is rather variable with carbon contents ranging from , $60 \mathrm{wt} \%$ to more than $90 \mathrm{wt} \%$ [24]. Nonetheless, organic matter detected by MLA underestimates the overall carbon content in the samples, by a rough estimate of $50 \%$ considering a high carbon content of $90 \%$. Three possible causes for systematic underestimation of TOC by MLA are identified: (a) a fraction of the organic carbon occurs as liquid hydrocarbons in the Kupferschiefer, commonly as minute inclusions within carbonate minerals [8]. Such organic matter would have been lost in the preparation of the sample blocks. However, this 


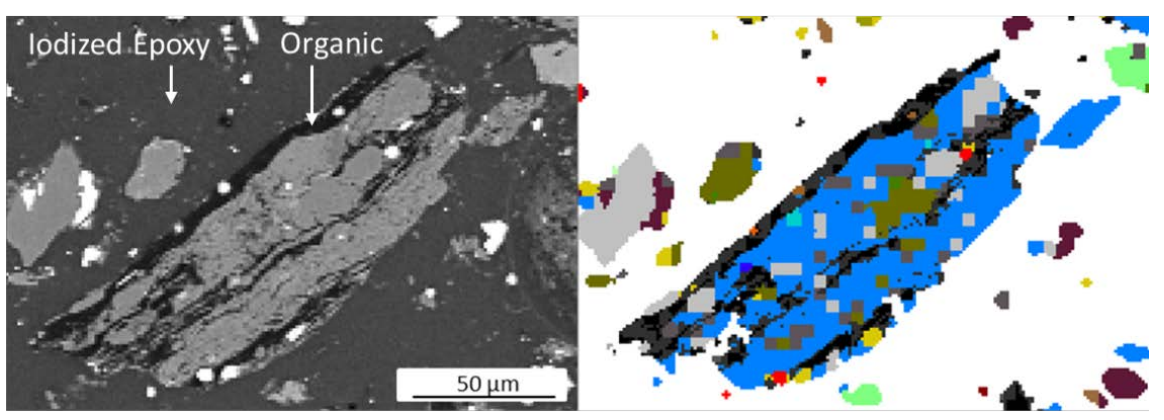

Figure 1. BSE image of a Kupferschiefer particle (left) and in MLA false colours (right) showing detection of organic matter and successful differentiation from the iodized epoxy resin. (MLA colours: black/ dark grey: organic matter, blue: sheet silicates, green: carbonates, light grey: quartz, red/ violet: copper sulphides).

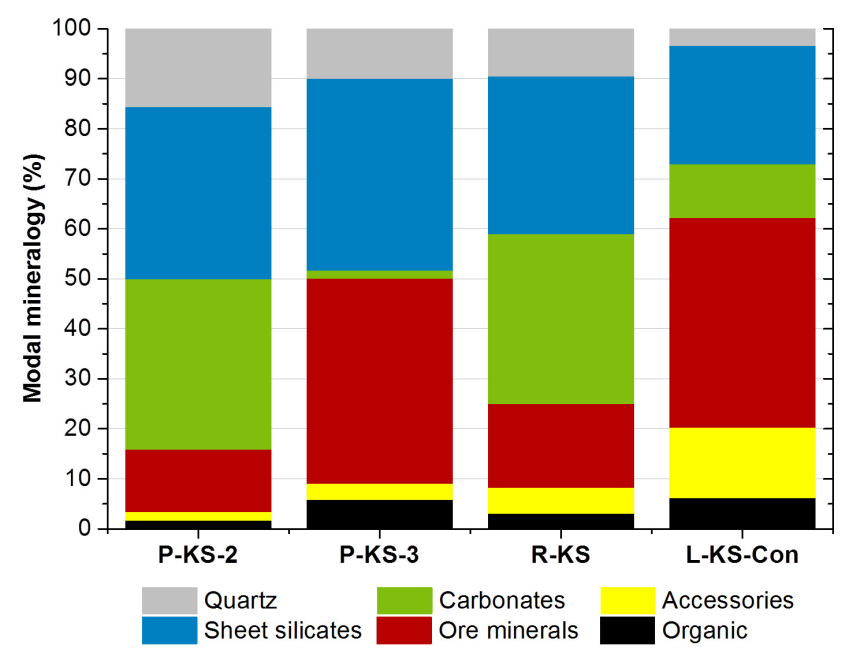

Figure 2. Modal mineralogy as determined by MLA.

Table 4. Overview of TOC concentration determined by chemical assay and organic matter detected by MLA.

\begin{tabular}{ccccc}
\hline & P-KS-2 & P-KS-3 & R-KS & L-KS-Con \\
\hline TOC (wt\%) & 3.46 & 9.60 & 7.40 & 9.10 \\
Organic matter (wt\%) & 1.80 & 5.96 & 3.19 & 6.23 \\
\hline
\end{tabular}

effect is regarded as minor. (b) Sample preparation may cause some degree of separation within grain mounts caused by the high density contrast between organic matter and (inorganic) minerals [25] and because of natural flotation effects that may affect the organic carbon. Again, we consider this effect as being rather minor; (c) The last source of error lies in the finely disseminated distribution of kerogen in the Kupferschiefer that commonly form bands less than $1 \mu \mathrm{m}$ in thickness. In fact, about $34 \%$ to $58 \%$ of all EDX-spectra identified as organic matter in this study show variable contributions from sheet silicates. Evidently, very thin bands or small aggregates of kerogen are thus not detected by MLA. This latter effect is regarded as very significant. The fine disseminated nature of the kerogen-as well as its compositional heterogeneity are regarded as the most 
important reasons for systematically underestimating $\mathrm{C}_{\text {org }}$ content by MLA. The relative size of these two effects remains unknown.

Not only does MLA data provide information on kerogen abundance, but it also allows to constrain the relationship between kerogen and (inorganic) minerals. More than half of the detected organic matter that was identified in the four samples is associated with inorganic minerals. Liberation is poor, with only $12 \%-30 \%$ of all organic carbon $>80 \%$ liberated (Figure 3 ). The mineral association of kerogen reflects to some degree the general modal mineralogy of the sample material. However, organic matter shows a weaker associated to ore minerals, carbonates, and quartz compared to sheet silicates and accessories. The strong association of organic matter to accessories is primarily caused by pyrite, of which L-KS-Con contains $12 \mathrm{wt} \%$ pyrite. Furthermore, the organic matter in the four particular samples appears to report preferentially to fine particle size fractions $(\mathrm{P} 50<10 \mu \mathrm{m}, \mathrm{P} 80<25 \mu \mathrm{m})$. Although the particularly fine-grained nature of the organic matter might increase the likelihood of density separation of fully liberated organic matter during sample preparation it has little ramification for the study of organic matter-inorganic mineral interaction.

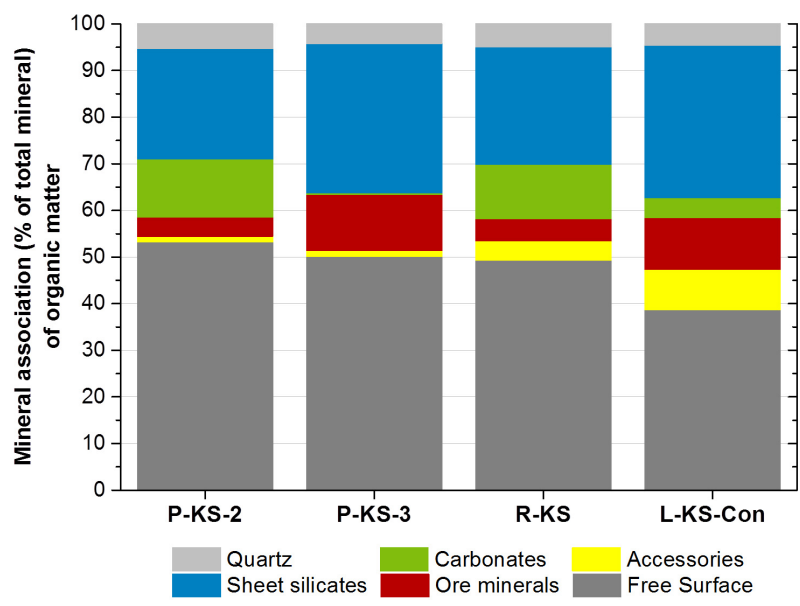

(a)

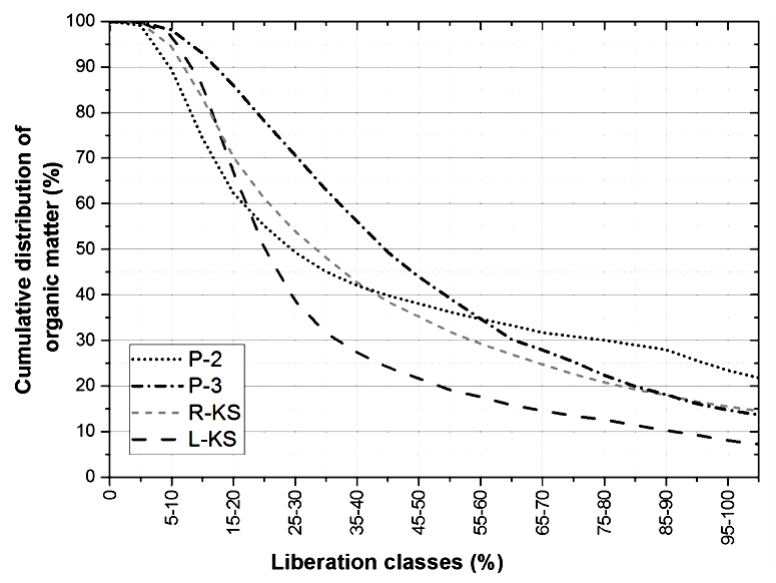

(b)

Figure 3. Plots illustrating the association of organic matter (a) and the liberation of organic matter within all samples (b). 
Of particular interest, of course, is the association and liberation of ore minerals-and their relation to solid organic carbon. Although $50 \%$ of the total surface of ore minerals is exposed (Figure 4(a)), 5\% - 23\% is in contact to organic matter. The effect of ignoring the presence of kerogen in this case is aptly illustrated in Figure 4(b). It increases the amount of detected free surface and indicates a vastly stronger association with accessories, primarily pyrite. As shown above, organic matter has a strong affinity to pyrite (Figure 3). Excluding organic matter from the analysis therefore leads to the deceptive conclusion that ore minerals are to a large fraction associated with pyrite, when instead it is the organic matter that has a stronger influence.

MLA measurements evidently grossly overestimate the liberation of ore mineral grains, when organic matter is not taken into account (Figure 5). Sample L-KS-Con and P-KS-3 were chosen to illustrate the effect, since they possess the highest concentrations of organic matter and copper minerals (Figure 2). The percentage of ore minerals found in the liberation class $50 \%-55 \%$ is reduced by about $10 \%$ in samples where organic matter was included.

The inclusion of organic matter in MLA analysis improved further the detection of whole particles and their correct sizes. Particles crosscut by bands of organic matter are split apart into multiple smaller particles without a distinction between organic matter and epoxy background. This effect is reflected in Figure 6 illustrating a trend towards larger particle size distribution of the inorganic minerals, when including organic matter in the MLA measurement. The inclusion of organic matter in the analyses increased the determined particle sizes by about $10 \%$.

\section{Conclusions}

This study shows that an assessment of the distribution of organic matter within Kupferschiefer can be achieved by automated SEM-based image analysis with the application of an iodized epoxy resin containing $15 \mathrm{wt} \%$ iodoform. This approach requires a more careful measurement setup to identify the appropriate BSE range, but it leads to much more accurate results regarding not only the

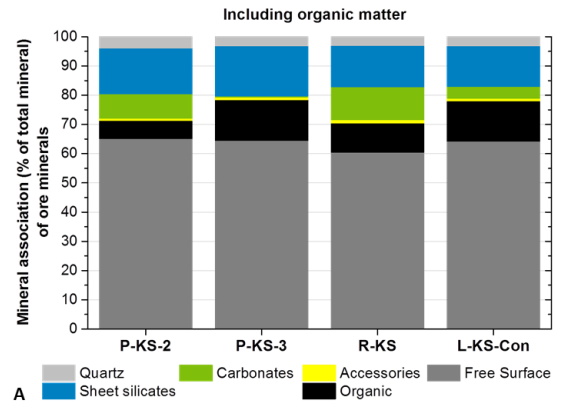

(a)

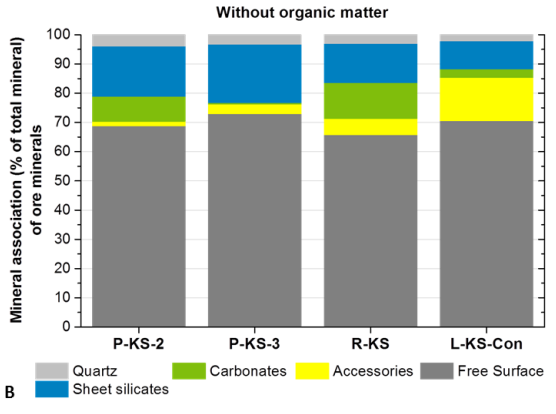

(b)

Figure 4. Plots illustrating the association of copper minerals (a) and the influence of organic matter on the determined liberation (b). 


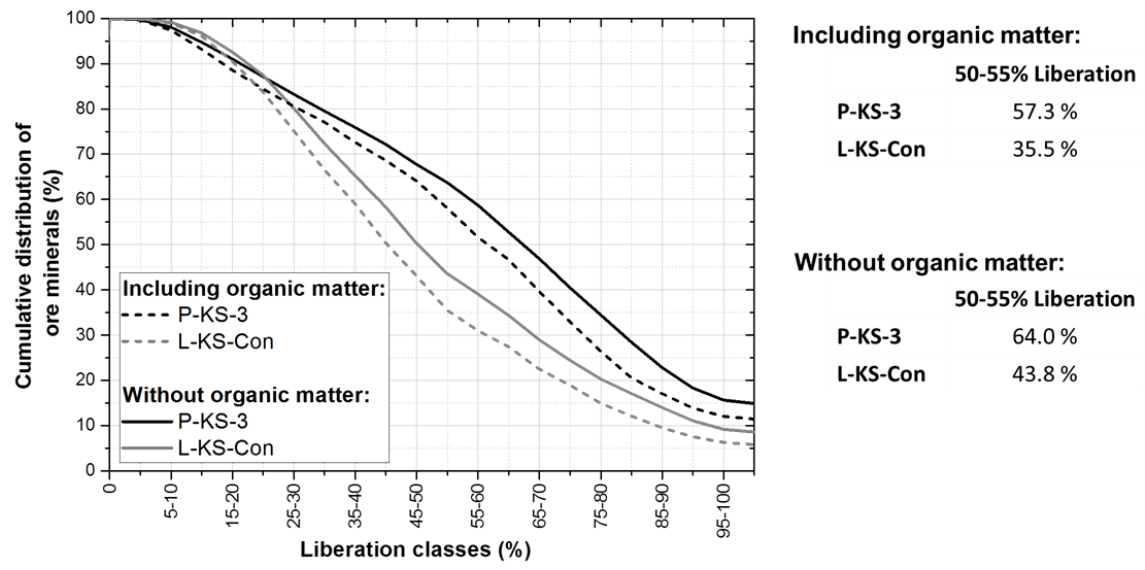

Figure 5. Plot illustrating the influence of organic matter on the determined ore mineral liberation.
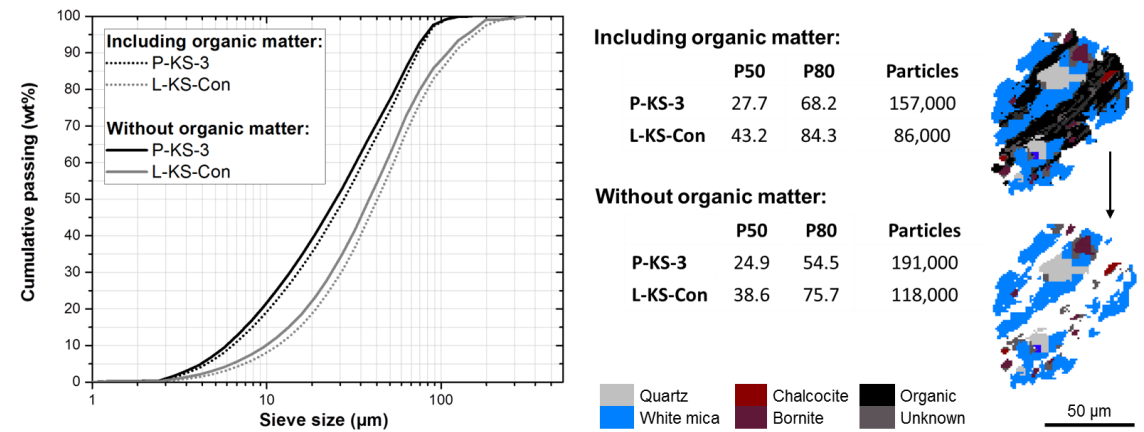

Figure 6. Change in particle size distribution of inorganic minerals as determined by MLA in the two most organic-rich samples P-KS-3 and L-KS-Con.

quantitative mineralogy, but also of all microfabric attributes relevant for process mineralogical studies. Ignoring the abundance of organic carbon-as commonly done in process mineralogical studies of ores rich in organic carbon-results in erroneous data that, in turn, may result in poor process design decisions.

The study also highlights the remaining difficulty to detect all solid organic carbon. This limitation, which is particularly relevant for ores in which the organic carbon is very finely disseminated cannot be overcome by current SEMbased image analysis.

\section{Acknowledgements}

Great thanks go to Roland Würkert and Andreas Bartzsch for their patience in testing different iodized epoxy resins. We would further like to thank Dirk Sandmann for his expertise and advice on the search for alterative media in the SEM-based image analysis of organic matter. The authors would also like to thank KGHM Polska Miedź S.A. and KGHM Cuprum who provided access to the mines and supplied samples of the copper concentrate. This work was part of the EcoMetals project and was financially supported by the German Ministry of Education and Research BMBF (Ref. Nr. 033RF001). 


\section{References}

[1] Hoal, K., Stammer, J., Appleby, S., Gregory, M., Woodhead, J. and Ross, J. (2009) Impacts of Quantitative Mineral Characterization on Processing. In: Malhotra, D., Taylor, P., Spiller, E. and Lavier, M., Eds., Recent Advances in Mineral Processing Plant Design, Society for Mining, Metallurgy, and Exploration, 79-84.

[2] Straszheim, W.E. and Markuszewski, R. (1990) Automated Image Analysis of Minerals and Their Association with Organic Components in Bituminous Coals. Energy \& Fuels, 4, 748-754. https://doi.org/10.1021/ef00024a023

[3] Creelman, R.A. and Ward, C.R. (1996) A Scanning Electron Microscope Method for Automated, Quantitative Analysis of Mineral Matter in Coal. Coal Geology, 30, 249-269. https://doi.org/10.1016/0166-5162(95)00043-7

[4] Sahyoun, C., Kingman, S.W. and Rowson, N.A. (2004) High Powered Microwave Treatment of Carbonate Copper Ore. European Journal of Mineral Processing and Environmental Protection, 4, 175-182.

[5] Borg, G., Piestrzynski, A., Bachmann, G.H., Püttmann, W., Walther, S. and Fiedler, M. (2012) An Overview of the European Kupferschiefer Deposits. Economic Geology Special Publication, 16, 455-486.

[6] Piestrzynski, A. and Pieczonka, J. (2012) Low Temperature Ore Minerals Associations in the Kupferschiefer Type Deposit, Lubin-Sieroszowice Mining District, SW Poland. Mineralogical Review, 62, 59-66.

[7] Bechtel, A., Gratzer, R., Püttmann, W. and Oszczepalski, S. (2001) Variable Alteration of Organic Matter in Relation to Metal Zoning at the Rote Fäule Front (LubinSieroszowice Mining District, SW Poland). Organic Geochemistry, 32, 377-395. https://doi.org/10.1016/S0146-6380(01)00002-X

[8] Püttmann, W., Fermont, W.J. and Speczik, S. (1991) The Possible Role of Organic matter in Transport and Accumulation of Metals Exemplified at the Permian Kupferschiefer Formation. Ore Geology Reviews, 6, 563-579. https://doi.org/10.1016/0169-1368(91)90047-B

[9] Sun, Y. and Püttmann, W. (2004) Composition of Kerogen in Kupferschiefer from Southwest Poland. Chinese Journal of Geochemistry, 23, 101-111. https://doi.org/10.1007/BF02868973

[10] Gize, A.P. (1993) The Analysis of Organic Matter in Ore Deposits. Society for Geology Applied to Mineral Deposits Special Publication, 9, 28-52. https://doi.org/10.1007/978-3-642-85806-2_3

[11] Kucha, H. (1993) Noble Metals Associated with Organic Matter, Kupferschiefer, Poland. Geology Applied to Mineral Deposits Special Publication, 9, 153-170. https://doi.org/10.1007/978-3-642-85806-2_10

[12] Kucha, H. and Wieczorek, A. (1988) Graphite in Kupferschiefer (Poland) and Its Genetic Meaning. Mineralium Deposita, 23, 174-178. https://doi.org/10.1007/BF00204297

[13] Matlakowska, R., Sklodowska, A. and Nejbert, K. (2012) Bioweathering of Kupferschiefer Black Shale (Fore-Sudetic Monocline, SW Poland) by Indigenous Bacteria: Implication for Dissolution and Precipitation of Minerals in Deep Underground Mine. FEMS Microbiology Ecology, 81, 99-110.

https://doi.org/10.1111/j.1574-6941.2012.01326.x

[14] Kutschke, S., Guézennec, A.G., Hedrich, S., Schippers, A., Borg, G., Kamradt, A., Gouin, J., Giebner, F., Schopf, S., Schlömann, M., Rahfeld, A., Gutzmer, J., D’Hugues, P., Pollmann, K., Dirlich, S. and Bodénan, F. (2015) Bioleaching of Kupferschiefer blackshale-A Review Including Perspectives of the Ecometals Project. Minerals Engineering, 75, 116-125. 
[15] Wieniewski, A. and Skorupska, B. (2016) Technology of Polish Copper Ore Beneficiation-Perspectives from the Past Experience. Mineral Engineering Conference MEC2016, 1-11. https://doi.org/10.1051/e3sconf/20160801064

[16] Liu, Y., Gupta, R., Wall, T.F. and French, D.H. (2005) Mineral-Mineral Associations in Pulverized Australian Coals. 5th Asia-Pacific Conference on Combustion, 117 120.

[17] Sutherland, D.N. and Gottlieb, P. (1991) Application of Automated Quantitative Mineralogy in Mineral Processing. Minerals Engineering, 4, 753-762.

[18] O’Brien, G., Gu, Y., Adair, B.J. and Firth, B. (2011) The Use of Optical Reflected Light and SEM Imaging Systems to Provide Quantitative Coal Characterisation. Minerals Engineering, 24, 1299-1304.

[19] Sandmann, D. (2015) Method Development in Automated Mineralogy. Dissertation, TU Bergakademie Freiberg, Institut für Mineralogie, 1-152.

[20] Gomez, C.O., Strickler, D.W. and Austin, L.G. (1984) An Iodized Mounting Medium for Coal Particles. Electron Microscopy Technique, 1, 285-287. https://doi.org/10.1002/jemt.1060010307

[21] Straszheim, W.E. and Markuszewski, R. (1992) SEM-AIA Measurement of the Association of Mineral Matter with the Organic Coal Matrix for Predicting Fine Coal Cleanability. Coal Preparation, 10, 59-75. https://doi.org/10.1080/07349349208905193

[22] Liu, Y., Gupta, R., Sharma, A., Wall, T., Butcher, A., Miller, G., Gottlieb, P. and French, D. (2005) Mineral Matter-Organic Matter Association Characterisation by QEMSCAN and Applications in Coal Utilisation. Fuel, 84, 1259-1267.

[23] Heinig, T., Bachmann, K., Tolosana-Delgado, R., Van Den Boogaart, G. and Gutzmer, J. (2015) Monitoring Gravitational and Particle Shape Settling Effects on MLA Sampling Preparation. Proceedings of IAMG 2015, 17 th Annual Conference of the International Association for Mathematical Geosciences, 200-206.

[24] Durand, B. (1980) Sedimentary Organic Matter and Kerogen: Definition and Quantitative Importance of Kerogen. Kerogen: Insoluble Organic Matter from Sedimentary Rocks. Editions Technip, Paris.

[25] Jackson, B.R., Reid, A.F. and Wittenberg, J.C. (1984) Rapid Production of High Quality Polished Sections for Automated Image Analysis of Minerals. Proceedings of the Australasian Institute of Mining and Metallurgy, 289, 93-97.

\section{Scientific Research Publishing}

Submit or recommend next manuscript to SCIRP and we will provide best service for you:

Accepting pre-submission inquiries through Email, Facebook, LinkedIn, Twitter, etc. A wide selection of journals (inclusive of 9 subjects, more than 200 journals)

Providing 24-hour high-quality service

User-friendly online submission system

Fair and swift peer-review system

Efficient typesetting and proofreading procedure

Display of the result of downloads and visits, as well as the number of cited articles

Maximum dissemination of your research work

Submit your manuscript at: http://papersubmission.scirp.org/

Or contact jmmce@scirp.org 